\title{
Degree Apprenticeships - a win-win model? A comparison of policy aims with the expectations and experiences of apprentices
}

\section{Sally Smith, Martha Caddell, Ella Taylor-Smith, Colin Smith, Alison Varey}

Centre for Computing Education Research, Edinburgh Napier University, Edinburgh, $U K$

Corresponding author: Sally Smith, s.smith@napier.ac.uk

Professor Sally Smith is Director of the Centre for Computing Education Research at Edinburgh Napier University.

Professor Martha Caddell is Professor of Learning \& Teaching Enhancement at Heriot-Watt University.

Dr Ella Taylor-Smith is Senior Research Fellow in the Centre for Computing Education Research within Edinburgh Napier University.

Dr Colin Smith is Associate Professor and leads on learning and teaching of computing at Edinburgh Napier University.

Alison Varey is Senior Lecturer and Project Director of Computing Graduate Apprenticeships at Edinburgh Napier University. 


\section{Degree Apprenticeships - a win-win model? A comparison of policy aims with the expectations and experiences of apprentices}

This article compares policy aims with experiences following the introduction of a new model for STEM apprenticeships in the UK. Degree apprentices work while studying for a degree, undertaking work-based learning and attending on-campus classes. Specifically, this study explores an implementation in Scotland, where computing degrees are designed and delivered through partnerships between employers, universities, and the Scottish Government's skills agency, Skills Development Scotland. This collaboration is designed to bridge employer-reported skills gaps and to bring about an increase in highly-skilled workers. To examine the policy implementation behind the new degrees, a review was conducted of the policy documents that framed their introduction, including texts from university and employer websites promoting apprenticeships. The apprentices' perspectives, barely addressed in the policy documents, were examined through surveys and narrative interviews. The policy documents positioned the new degrees as a 'winwin' opportunity for employer-led higher education, and the apprentices recognised and valued the opportunity to undertake a work-based degree. However, underneath the superficial win-win narrative a complex implementation landscape was observed for employers, apprentices, and universities. Understanding these stakeholder contexts is essential for the longer term sustainability of degree apprenticeships.

Keywords: work-based learning; work-integrated learning; graduate apprenticeship; degree apprenticeship; computing

\section{Introduction}

For many, higher education is seen as a gateway to a well-paid career through the human capital bestowed by a degree (Schultz 1961), with universities functioning to provide a supply chain of skilled graduates for employers (Wilson 2012). In practice, the interface between higher education and the graduate workplace is complex, with employers influencing the curriculum by liaising with universities directly or through professional bodies (Hordern 2014). As a response to employers’ concerns about skills shortages (Smithers 2016), a new UK Government policy on degree apprenticeships was introduced as a purposeful approach to higher-level skills development directly 
focused on employers’ needs (Institute for Apprenticeships 2017).

While the drivers for these new degrees are similar across the UK, their implementation differs in terms of the responsibilities of the various actors involved: employers, higher education institutions (HEIs), and funding bodies. England was first to launch degree apprenticeships, in 2015, and the policy implementation there has recently been reviewed (Policy Connect 2019; Powell 2019). This work responds to the need to investigate and reflect upon the distinct Scottish policy implementation, which commenced in 2017. This is pursued through analysis of published policy documents and websites, together with empirical research examining the situated perspectives of the first apprentices at a Scottish university. Understanding implementation is important since the policy represents significant funding, and implies a potentially disruptive approach to higher education, with employers having greater influence over the curriculum than in other education policy models (Hordern 2014).

\section{Models for degree apprenticeships}

Predating graduate apprenticeships, employers and HEIs have a long history of collaboration on work-based learning courses that create workplace learning opportunities (Boud and Solomon 2001) and acknowledge this by means of academic credit (Feldmann and Sprafke 2015; Mulkeen et al. 2017). Curriculum development in these contexts has previously been, in the main, the domain of HEIs (Hordern 2014). However, such curricula and interventions have not led to sufficient graduates having, for example, the STEM skills that employers argue are required (Shadbolt 2016; Wakeham 2016). The challenges of constant technological evolution (e.g., Radermacher and Walia 2013), combined with a decline in employer training investments (Green et al. 2016), mandated a new approach to address the STEM skills gap. 
The degree apprenticeship agenda in the UK aims to improve the match between graduates’ skills and employers' needs (BIS 2016; Lambert 2016), while capitalising on the generally favourable public opinion of apprenticeship models of education and training (Hodgson, Spours, and Smith 2017). The Richard Review (2012) suggested ways to adapt the apprenticeship concept to contemporary needs and create "clear, effective and trusted qualifications” (p6), funded through a training levy. The apprenticeship levy (0.5 per cent of salary costs paid by all employers with an annual pay bill of over $£ 3$ million) was introduced across the UK from April 2017 (Powell and Walsh 2018). The thrust of degree apprenticeships was for apprentices to obtain a degree, rather than an 'equivalent’ qualification (Policy Connect 2019). The levy would fund these employer-led degree apprenticeships.

In England, apprenticeship policy implementation involves employers specifying the skills they need and collaboratively creating the apprenticeship standards (lists of required competencies) that guide assessment in each subject (Hodgson et al. 2017; Institute for Apprenticeships 2017). Employers negotiate with HEIs to implement specific degree apprenticeships (Powell and Walsh 2018). There have been some implementation challenges, including concerns about the ability of employers to design courses (Mulkeen et al. 2017). More specifically, Bathmaker (2013) found a range of concerns about the dominant role of employers in designing vocational qualifications in England, including an emphasis on generic skills rather than knowledge. To counteract concerns around the extent to which employers influence courses, Bravenboer (2016) recommends that universities should not be excluded from the process of framework development. In Germany, a similar disconnect between educational institutions and industry led to a re-examination of work-based learning and the emergence of the German Dual Apprenticeship System (Gessler and Howe 2015). Gessler and Howe 
recommend an approach which aggregates employers’ skills demands in order to identify an overarching definition of occupational competence. This aggregation manages multiple employer voices with a view to ensuring that no single specific workplace context dictates the work-based learning activity. This is akin to the policy implementation approach in Scotland.

\section{Policy implementation actors and agencies}

While policy implementation researchers have debated intensely the merits of topdown, bottom-up, or synthesised approaches, there is as yet no widely agreed theoretical approach to conducting policy implementation studies (Hupe 2014). With relevance to this study specifically, no conclusion has been drawn about how layers of implementation are best considered (Goggins et al. 1990; Hill and Hupe 2014). The aim of the policy on apprenticeships is a normative type, namely the expression of an ideal to be realised through implementation (Hupe and Hill 2016). This work aims to compare policy aims with practice, and as such is a mainstream study with a “downward” theoretical approach (Hupe 2014, 170). Analysis of policy implementation should start with the identification of actors and agencies (Hjern 1982; Pülzl and Treib 2017) forming the structures within which policy execution occurs (Sabatier 1991). We started by identifying the agents and actors responsible for the Scottish policy implementation, represented in the structure shown in Figure 1, with each agency's responsibilities noted. Degree apprenticeships are termed Graduate Apprenticeships and are designed and implemented through a partnership of skills agency Skills Development Scotland (SDS), employers, and HEIs. 


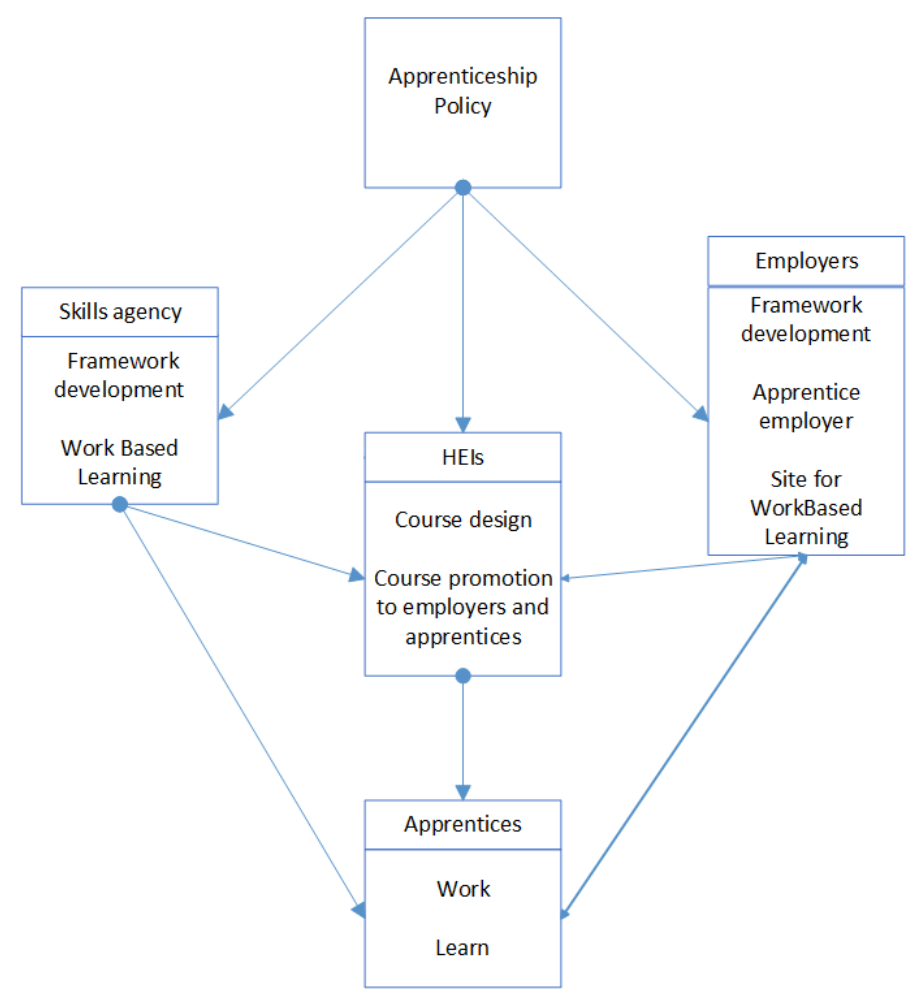

Figure 1: Overview of policy implementation actors and agents

SDS brings employers together to develop the frameworks (currently 12, in mostly STEM areas) that define the apprenticeships (SDS 2018). These frameworks are the aggregation of multiple voices. In the case of computing, previously accredited course outlines were adopted from the Tech Partnership, an established employer network (Tech Partnership Degrees 2019).

HEIs bid competitively for apprenticeship places on these frameworks and are awarded funded places by SDS. HEIs then develop courses aligned to the frameworks, and promote these to employers and potential apprentices. Employers can recruit individuals directly into an apprentice role or identify potential apprentices from amongst existing staff. Once the courses begin, the collaboration between HEIs and employers is realised through the experiences of the apprentices. No less than $20 \%$ of the apprentices’ time should be spent on non-workplace learning (Powell 2019). The 
remaining learning is through work-based credit accumulation, which should be defined via collaboration between employers and HEIs and supported by academic and employer mentoring (SDS 2016a). Inspired by Elmore’s (1979) “backward mapping” approach, Hupe and Hill advocate assessing new policy implementations by trying to establish the "extent to which a new policy makes a difference to everyday life” (2016, 114). Examining the perspectives of the apprentices provides a means to explore how the policy implementation is experienced.

In this study, the apprenticeships considered are oriented to Computing/IT. This sector is diverse and fast-changing, relatively new and comparatively 'open', employing graduates of computer science, graduates of other disciplines and non-graduates; both the level and specificity of skills needs are diverse (Donnelly et al. 2011). So, while the IT profession encompasses status, skills, methods, and standards (Thompson 2008), the breadth of activity spans a range of technologies and underpinning knowledge, with employers favouring diverse technologies and working practices. Two of the three (Scottish) frameworks in computing were based upon existing industry-accredited curricula (BSc Information Technology with Business and BSc Software Development). The third (BSc Cyber Security) was developed through a Technical Expert Group made up of employers' representatives and employer bodies.

In policy implementation terms, it is important to ask whether becoming a skilled worker (the main aim of the policy being to create skilled workers) is also the main motivation for apprentices. Motivations and expectations of university study for on-campus students are reasonably well-understood: to have a career and earn money; for personal development; to use their education to support others; in response to family and friends' expectations (Balloo, Pauli, and Worrell 2015), and the chance of a new start and to build skills and knowledge (Money et al. 2017). Apprentices, for whom both 
university and the workplace act as learning and social environments, are likely to have distinct expectations and motives for study. In addition, situated views on current skills and on skills development needs, as identified by apprentices, may affect the extent to which technical skills development is an important motivation, as compared to, for example, acquiring a recognised award.

\section{Study aims}

The discussion above indicates a number of places where the relationships between policy agents involved in implementing the new apprenticeships intersect to form the implementation structure (Hjern 1982). To explore the relationships between policy and implementation, this study posed the following questions:

1. How are the aims of the apprenticeship policy framed in the policy documents?

2. How do HEIs express the policy aims to attract employers and apprentices; and how do employers promote the apprenticeship proposition?

3. How are the aims reflected in the situated perspectives (everyday lives) of the first cohorts of apprentices?

\section{Methodology}

The methodology was designed to reflect the normative nature of the apprenticeship policy: to explore both the ideals and the actual experience. In exploring policy implementation we focus on four distinct sets of voices (Figure 1): the skills agency (SDS); HEIs offering the degrees; employers offering apprenticeship roles; and the apprentices embarking on apprenticeships. In traversing policy implementation by these actors, the focus is on implementation discord between the high-level policy aims and the lived experiences, an approach recommended by Hupe et al. (2014). Firstly, the policy context is surfaced through analysis of documents published by the skills agency (Data Source A) and promotional materials developed by HEIs (B) and employers (C). This is then compared with the experiences of the new apprentices at one university, 
explored through a survey and narrative interviews (D). Table 1 provides an overview of the data sources.

Table 1: Overview of data sources

\begin{tabular}{|c|c|c|}
\hline Data Source & Data Type & Nature of data \\
\hline A & Funding call & Document - SDS2016a \\
\hline A & Technical specifications & Document - SDS2016b \\
\hline A & Principles of Work-Based Learning & Document - SDS2016c \\
\hline B & $\begin{array}{l}\text { HEI Recruitment (of apprentices and } \\
\text { employers) websites }\end{array}$ & $\begin{array}{l}n=7 ; \text { HEI provider websites, visited between } 1^{\text {st }} \\
24^{\text {th }} \text { May } 2018\end{array}$ \\
\hline $\mathrm{C}$ & Adverts for apprenticeship positions & $\begin{array}{l}\mathrm{n}=8 ; \text { Adverts on apprenticeships.scot } \\
\text { representing all live adverts between } 1^{\text {st }-17^{\text {th }}} \\
\text { December } 2018\end{array}$ \\
\hline $\mathrm{D}$ & Survey of apprentices & $\mathrm{n}=47$ \\
\hline $\mathrm{D}$ & Narrative interviews with apprentices & $\mathrm{n}=15$ \\
\hline
\end{tabular}

\section{Document review (Data Sources A, B, C)}

Identifying tensions between perspectives can serve to reveal the way general rules are "shaped and tailored” to implement apprenticeship policy in local contexts (Sausman, Oborn and Barrett 2016, 564). Documents and web pages published by SDS, employers, and HEIs offer a window through which to explore policy intent and its subsequent interpretation and implementation (Ball 2012; Powell and Walsh 2018).

We undertook a document analysis (Bowen 2009) relating to the launch of graduate apprenticeships in Scotland, in order to unearth the interplay between different stakeholder perspectives. The documents written by SDS (A) to introduce apprenticeships are of particular significance, given their critical role in mediating between policy aims and practical development and implementation. To reveal implementation themes, we also reviewed materials published via the web pages of those HEIs who launched apprenticeships in the first tranche (B), and employers advertising apprenticeships on the apprenticeship website (C). These webpages expressed the way the policy implementation was signposted to potential apprentices.

The review approach adopted was similar to exploring interview or ethnographic data (Silverman 2016), identifying emerging themes via coding, and working through those to explore common areas and distinctive contexts (cf. Braun and Clarke 2006). 
This then formed the basis for analysis of where certain perspectives and voices were dominant and - crucially - where particular voices were given less space.

\section{Survey and interviews with new computing apprentices (Data Source D)}

The voices of the apprentices themselves were captured at the beginning of their courses, through a survey. This was conducted with the first and second cohorts on paper during their induction days, in September 2017 (n=22) and September 2018 $(n=47)$. All apprentices who attended the induction days completed the survey, designed to gather information about their backgrounds and work contexts, including their paths into IT and the apprenticeship, and to explore their main motivations to study, especially their desired skills.

In addition, interviews were conducted with apprentices in the first cohort, sixto-eight months into their course. All apprentices were encouraged to participate; fifteen volunteered and were interviewed. Narrative interviews encourage participants to describe their lives as a series of events and attempt to make sense of their trajectories (Dziallas and Fincher 2016). Various precedents inspired this approach to investigating the apprentices' journeys into, and situated experience of, the new degrees, including Dziallas and Fincher (2016), Smith et al. (2017) and UCAS (2017). A realist approach was taken to the interviews: the participants' narratives were valued (and interpreted) as their individual perspectives and also as accounts describing aspects of the implementation of apprenticeships, according to their specific contexts (Braun and Clarke 2006; Maxwell and Mittapalli 2011). The interview protocol focused on the apprentices' experience of education and work, from school to the present, including the example and influence of their family, friends, teachers, colleagues, and employers. Each interview lasted around one hour, was audio-recorded and transcribed (intelligent 
verbatim). The transcripts were analysed using thematic analysis (Braun and Clark 2006), progressively coding to identify and map the themes and sub-themes. Survey responses and interview transcripts were anonymised and participants provided informed consent.

\section{Findings}

In Scotland, SDS undertook the key role of translating policy into tangible funding propositions. The documentation provided to institutions involved in bidding for apprenticeship places offers a snapshot of how policy intent was translated into calls for practical action (SDS 2016 a, b, c).

\section{Understanding the policy aim through policy documents (Data Source A)}

Tender documents and technical specifications (for each degree) were developed and disseminated to potential apprenticeship providers (SDS 2016b). These consistently highlighted that the model was founded on an interest in meeting employer needs. However, apprenticeships would provide sector-relevant skills as opposed to employerspecific training, supporting the "education and development of employees so that they acquire the necessary skills, knowledge and competence necessary to work and progress in the sector" (SDS 2016b, 4). Thus, while the focus was on employers as partners in the development of apprenticeships and on employing individual apprentices, broader outcomes included an emphasis on sufficiently general skills for mobility across the sector.

The distinction between "traditional learning based primarily in an educational establishment” (SDS 2016c, 3; 2016b, 3) and the apprenticeship model, where learning was to be delivered and assessed in the workplace, was emphasised. Inclusion of creditbearing, work-based learning was mandated to enable degrees to be accelerated: a win 
for employers and apprentices. Underpinning this was a strong emphasis on employer engagement at all stages of the process, from the initial development of specifications, via technical expert groups, through to the commitment for employers to work alongside HEIs to support apprentices through learning and assessment. To be successful, HEIs' bids for places were “to exemplify how the programmes differ from the current offerings" (SDS 2016a, 15).

Flexible provision was mandated, in light of the diverse pathways apprentices could take into and through their studies (SDS 2016b). As such, the emphasis was on new vocational routes to a degree. The tension between employer demand and individual pathways was evident in the Principles of Work Based Learning document which recognised that,

“...one of the objectives of work-based learning in Advanced and Graduate Apprenticeships is supporting learners to achieve professional standards or standards of a regulatory body” (SDS 2016c, 9).

There was some consideration of recognition of prior learning in relation to entry routes and, potentially, credit-accumulation at later stages of study (SDS 2016b, 8); there were references to the flexible curriculum and graduate attributes and to ensuring engagement with widening access priorities (SDS 2016a, 10).

Finally, throughout the documentation, the terms apprentice and employee were used, rather than student, emphasising the primary focus on the relationship between the individual and the workplace and the efforts to ensure preparedness for professional recognition. The relationship with the university was less visible. While the end-point qualification was referred to, and the term graduate was utilised to highlight end-ofapprenticeship achievement (see e.g., SDS 2016c, 5), the relationship to the university during the course of study was given limited attention. Indeed, connection to the 
university was emphasised by an interest in negotiating "a minimum required attendance on campus” (ibid.). The value added through the relationship with the university and what the apprentice or, indeed, the employer, may wish to get from that connection was given limited space. Graduateness (articulated as skills, professionalism, workplace reflection) (SDS 2016c, 9) was represented as an endpoint of apprentice achievement, with the value of university engagement or being a student remaining somewhat unacknowledged.

\section{Attracting participation: HEI representations of apprenticeships (Data Source}

\section{B)}

Apprenticeship policy implementation was further illuminated by exploration of the online materials created to promote the apprenticeship places by HEIs. All HEIs implemented dedicated webpages to promote their apprenticeship offerings both to employers and to potential apprentices. Common terminology was used which broadly reflected the main thrust of the wider apprenticeship discourse with 'learn while you earn' and the advantages of 'having a job rather than having to search for one when you graduate' as key threads in resources targeted at potential apprentices. Similarly, the employer-focused discourse played out strongly, with an emphasis on meeting specific

(future) skills needs and the cost-effective opportunity presented by the apprenticeships. "Bringing together the worlds of work and study" (Heriot-Watt 2018) is, the website heralds, a win-win scenario for apprentices, employers and, indeed, the HEI.

While the novelty of the apprenticeship approach was stated and contrasted with traditional approaches to learning, HEI materials emphasised their prior credentials of working in partnership with employers and delivering work-based learning over an extended period. Graduate employability rates and lists of current collaborations with employers were used to demonstrate why employers should partner with that institution. 
One highlighted their "decades of experience of working with employers to design programmes that enable employees to study and learn new skills while maintaining workplace productivity” (Robert Gordon University 2018). Another presented themselves as an "industry-focused university" (UWS 2018). The promotion of the novelty of the graduate apprenticeship was thus tempered by an emphasis on existing experience of partnership-building with industry and institutional experience of workbased learning approaches. University experience and pedagogic expertise was presented as key to ensuring the quality of experience for employers and apprentices.

Beyond the ‘learn as you earn’ mantra, the everyday life proffered to learners was presented in terms of financial benefits and career acceleration. The fully-funded nature of apprenticeships, their efficiency, and the potential to negotiate travel and other expenses with employers were emphasised. Many noted that apprentices would not need to look for a job after graduation, as the individual would already be employed, stressing the competitive positional advantage offered by an apprenticeship.

In the HEI materials, emphasis was placed on the dual roles of student and employee. While the term student was noticeable by its absence in the SDS documentation, the HEI literature emphasised that individuals would be matriculated full-time students and benefit from all the concomitant services and support. The HEIs used case studies which also emphasised this combined role. Personal testimonies highlighted the previous career pathways of learners, their interest in remaining in employment, and flexible study routes. The importance of the degree as an enabler for career progression alongside workplace experience was integral to this self-presentation - including case studies highlighting that this was an alternative route to a degree for those who might otherwise not have considered this option. 
Attracting participation: Employer representations of apprenticeships (Data Source C)

Employers’ policy implementation perspectives were surfaced by reviewing adverts for apprenticeship places on SDS’ apprentice opportunities website (https://www.apprenticeships.scot/) where policy intent was expressed through employer messages to prospective apprentices. The ‘Earn while you learn' theme appeared (translated) in adverts as an invitation to become an employee with a starting salary and other benefits of employment; tuition fees would be covered; and there would be one day per week set aside to attend the course.

While HEIs promoted previous industry partnerships to establish their credentials, many employers did not even mention their HEI partner in the advert. Degree titles were mentioned but little specific association with the degree provider. In one case the employer referred to the degree awarding body as a "training partner", somewhat downplaying both the opportunity to be a matriculated student studying towards a degree and the status of the HEI. Instead, those browsing adverts were encouraged to think about what a typical day might look like, with the emphasis on company organisation, projects and worksites. As with the HEI promotional material, the apprentice 'wins' were salaries and obtaining a degree with no fees to pay. Other selling points included opportunities to join global organisations or high-performing teams and various work culture and practices were included. Qualifications were expressed as typical university entrance qualifications (“or equivalent”), with little acknowledgement of flexible entry routes. Adverts also listed desired qualities of applicants, including personal attributes such as passion, drive, and commitment. None of the adverts reviewed mentioned professional standards or membership of a professional body. 
From the policy documents, HEI and employer material reviewed, a picture of two beneficiary groups emerged: employers, who would lead the development of this new model for education, and apprentices who would gain debt-free skills for a graduate career in the IT sector. However, there was no attempt to predict or anticipate the perspectives of the apprentices themselves.

\section{The 'everyday lives' of the apprentices (Data Source D)}

The situated perspectives of the apprentices cast light on the alignment of the policy documents, and subsequent marketing narratives, with the apprentices' everyday lives. The apprentices’ backgrounds, motivations and experiences were captured by a survey and narrative interviews. The findings are based on analysis of the data most relevant to the policy ideas described above: building appropriate skills in the digital sector, based on employer input; and the win-win of earning and learning for employers and apprentices.

Findings from the survey: becoming a skilled IT worker

The survey results gave an overview of the demographics of the computing apprentices in the university’s first two cohorts (2017 and 2018), summarised in Table 2.

Table 2: Survey respondents (computing apprentices in the first two cohorts)

\begin{tabular}{r|c|c|c|c|c|c|c|c|c|c}
\hline & \multicolumn{2}{|c|}{ Gender } & \multicolumn{2}{c|}{ Age } & \multicolumn{2}{c|}{ Ethnicity } & Parents' HE? & With current employer \\
\hline & Female & Male & $\begin{array}{c}\text { Under } \\
\mathbf{2 6}\end{array}$ & $\begin{array}{c}\text { Over } \\
\mathbf{2 6}\end{array}$ & $\begin{array}{c}\text { White } \\
\text { UK }\end{array}$ & $\begin{array}{c}\text { White } \\
\text { Non-UK }\end{array}$ & $\begin{array}{c}\text { Neither } \\
\text { attended } \\
\text { uni }\end{array}$ & $\begin{array}{c}\text { One or } \\
\text { both } \\
\text { did }\end{array}$ & $\begin{array}{c}\text { Recruited } \\
\text { for GA }\end{array}$ & $\begin{array}{c}\text { Already } \\
\text { employed }\end{array}$ \\
\hline $2017(n=22)$ & $18 \%$ & $82 \%$ & $68 \%$ & $32 \%$ & $82 \%$ & $14 \%$ & $27 \%$ & $77 \%$ & $18 \%$ & $82 \%$ \\
\hline $2018(n=47)$ & $19 \%$ & $81 \%$ & $77 \%$ & $23 \%$ & $94 \%$ & $6 \%$ & $47 \%$ & $47 \%$ & $50 \%$ & $50 \%$ \\
\hline Combined $(n=69)$ & $19 \%$ & $81 \%$ & $74 \%$ & $26 \%$ & $90 \%$ & $9 \%$ & $41 \%$ & $66 \%$ & $40 \%$ & $60 \%$ \\
\hline
\end{tabular}

In 2018, apprentices were also asked for their postcode and this was categorised according to the Scottish Index of Multiple Deprivation (SIMD): 12\% of addresses were in the most deprived quintile (Q1) and 20\% were in the least deprived (Q5). In 2018, 
apprentices were asked about their previous higher education experiences: $13 \%$ had completed a university degree and $21 \%$ had started one but not completed it. Over both years, most of the apprentices were already in-post with their employers before starting the course, while $40 \%$ were recruited to become graduate apprentices. Notably, the proportion recruited into their role more than doubled (from 18\% to 50\%) between the two years, probably due to diffusion of information about the programme and more time for recruitment in 2018. The survey asked "What are your main aims in undertaking this apprenticeship degree?” Themes were identified in the free-text responses and the main aims are shown in Table 3. Most participants focused on gaining knowledge and skills, in line with the policy aim to increase Scotland's digital skills base (see Taylor-Smith et al. 2019 for more detail).

Table 3: Participants' reasons for undertaking the apprenticeship degree

\begin{tabular}{l|l}
\hline Aims & Participants who mentioned aim \\
\hline Gain knowledge and skill & $65 \%$ \\
\hline Gain degree qualification & $35 \%$ \\
\hline Improve career/ options & $35 \%$ \\
\hline To continue employment/ gain work experience & $17 \%$ \\
\hline To benefit employer/ organisation & $13 \%$ \\
\hline Professional/ personal growth & $12 \%$ \\
\hline Towards financial reward & $6 \%$ \\
\hline
\end{tabular}

In terms of skills, the objectives of participants centred on coding/programming and project management. They mentioned benefits to their employer, e.g., "To develop my skills for me and [my] company”. Asked why they chose the apprenticeship degree rather than a traditional full-time degree, over half the apprentices referred to the integration of work experience and a quarter mentioned keeping their current job. Both responses closely reflect the broad policy aim of skills aligned with employers/ employment.

Narrative interviews were conducted with fifteen apprentices in the first cohort. 
Two interviewees had joined their company specifically to do the apprenticeship; five were female. A dataset was created of interview data which was relevant to the policy and promotional themes described above, whether aligned or tangential to these themes. This data was analysed to identify the apprentices' contexts and perceptions. Findings from this thematic analysis are presented below, structured according to apprentices’ perceptions of the benefits of the apprenticeship, followed by the challenges they experienced in practice.

Recognisable policy outputs: the employer-apprentice win-win in everyday lives The apprentices’ perspectives were observed to be closely aligned to the win-win narrative in their recognition that the graduate apprenticeship was a great opportunity for them: fees were paid and they were earning a salary while studying. Two interviewees described this opportunity as an easy decision, with one recounting his manager saying “It seems like a no-brainer. You’re getting one day a week .... your salary’s staying the same” (Interviewee 5). This also reflected the "Work, earn, learn” message from HEIs. All the interviewees talked about the alignment between their work and study; they had been able to put knowledge from study into practice at work almost immediately, an indication of engagement with real-world problems (Lemansky et al. 2011). The impact of the policy on employers was also recognised by apprentices through descriptions of how they were applying their enhanced skills. One apprentice described how: “I’m now learning stuff that I’ll go back to [my] team and just say 'Right, we've got this information just now, can we sort of change it about? I think this would be a really good idea’” (Interviewee 3). Three interviewees had identified, with their colleagues, a skills gap in their organisation, which they could potentially fill: "I’ll be able to bring that to the table and then use those skills in the workplace -spread knowledge, mainly, help out here as best I can” (Interviewee 13). 
Interviewees also described benefits for their employers beyond application of their new skills. For example, apprentices describe using their skills to help to advance their organisations: "I try and push my own development, and use that to help push our unit forward, make us a better unit" (Interviewee 2); "in the long term then, the stuff that I learn, I can help with the business moving forward” (Interviewee 3). These examples go beyond the principles of integration of learning in the workplace (Lemanski, Mewis, and Overton 2011) by providing strategic employer benefitsanother win for employers. While the focus on skills reflects the central strand of the policy aims through the win-win narrative, there was a strong theme of positive personal growth associated with this learning opportunity, beyond acquiring skills for employment. For example, one interviewee described the opportunity to "make yourself better, to see what avenues can open up” (Interviewee 5). In line with the data gathered through the survey, apprentices recognised the degree as career enhancing; three specifically mentioned a related increase in earnings. Two mentioned increased loyalty through a commitment to staying with their employer throughout the four-year degree and had committed to working hard at university, because it was salaried time. However, in contrast to the stated policy aim of creating a pipeline of new skilled entrants, over half the interviewees were already well-established in their jobs when they started the apprenticeship; they recognised this new opportunity to gain recognition and/or upskill and felt that this opportunity had come at the right time in their lives. For example, some described gaining motivation to study that they did not have when they left school, like Interviewee 4: “But now I think I’ve reached a point where I can do some extra learning, like doing this degree, but enjoying it at the same time, because I enjoy my work." 
There was no sense of the apprentices recognising their study as explicitly employer-led, either in terms of curriculum design or implementation. However, most of the interviewees described ways in which their employers and colleagues supported their studies or planned to in the future. Some apprentices had discussed, with their managers, opportunities to move to roles or departments aligned to future study. There was an emphasis on workplace mentors in the policy documents, whose role would be to support the apprentice and ensure meaningful work-study integration (e.g., Mulkeen et al. 2017). However, several interviewees were unsure who their mentor was; one apprentice specifically noted “Workplace mentor, that's another thing...we've never once sat down with any member at work and gone through learning agreements” (Interviewee 12).

The main challenge voiced by the apprentices was to balance the dual demands of work and study, while retaining a personal life. Most of the interviewees found some time at work or on their university day to do course-related work. However, for about a third of them, this was not possible due to their work roles and, for them, strategies included setting aside weekend time. Several described university staff as helpful in this context: “...you understand, because we’ve got full-time jobs, it’s not as easy just to do things as like a normal student would” (Interviewee 4) (authors’ emphasis). The general picture was positive: “I’m enjoying it. I would definitely recommend it for anybody that's considering it.” (Interviewee 5).

\section{Discussion}

The aims of the apprenticeship policy were to deliver better-targeted and timely delivery of skills into the supply chain: a wider pool of more highly-skilled workers. A win-win theme emerged from both policy documents and from materials designed to encourage participation: employers benefiting from increased access to more highly- 
skilled workers; the apprentices benefiting from work and a degree award. The aims would be realised in two ways: an employer-led curriculum and new pathways into the IT sector, leading to an increase in the supply of skilled workers. The findings relating to policy implementation amongst the policy agents (as set out in Figure 1) are summarised in Table 4.

Table 4: Analysis of policy implementation agents' approach to meeting policy aims

\begin{tabular}{l|l|l|l|l}
\hline $\begin{array}{l}\text { Policy agent / } \\
\text { Main aims }\end{array}$ & Skills Agency & HEI & Employer & Apprentice \\
\hline $\begin{array}{l}\text { Employer-led } \\
\text { Curriculum }\end{array}$ & $\begin{array}{l}\text { Articulated clearly } \\
\text { in policy } \\
\text { implementation } \\
\text { documents and } \\
\text { frameworks }\end{array}$ & $\begin{array}{l}\text { Framework- } \\
\text { compliant courses } \\
\text { advertised }\end{array}$ & $\begin{array}{l}\text { Somewhat limited - } \\
\text { some employers } \\
\text { active on Technical } \\
\text { Experts Group }\end{array}$ & $\begin{array}{l}\text { Articulated as } \\
\text { supporting work-based } \\
\text { teams and projects }\end{array}$ \\
\hline $\begin{array}{l}\text { Increased } \\
\text { supply of skilled } \\
\text { graduates }\end{array}$ & $\begin{array}{l}\text { Expressed as an } \\
\text { aspiration to look at } \\
\text { different entry } \\
\text { points and non- } \\
\text { standard entrance }\end{array}$ & $\begin{array}{l}\text { Little visible } \\
\text { evidence of } \\
\text { meaningful support } \\
\text { for non-standard } \\
\text { entrants }\end{array}$ & $\begin{array}{l}\text { Little visible } \\
\text { evidence of } \\
\text { meaningful support } \\
\text { for non-standard } \\
\text { entrants }\end{array}$ & $\begin{array}{l}\text { Some evidence of } \\
\text { upskillers/existing } \\
\text { employees with non- } \\
\text { standard degree } \\
\text { entrance qualifications }\end{array}$ \\
\hline
\end{tabular}

\section{Implementation of the employer-led curriculum as a policy aim}

The employer-led curriculum was realised through frameworks, with sector need taking precedence over individual employers’ needs. The apprentices interviewed had all applied new knowledge and skills to their workplaces. Indeed, some already showed insights around the potential for their workplace process and practices to be improved. Reflecting policy aims, the acquisition and work-place application of computing skills are evident in the apprentices’ narratives, as found elsewhere (e.g., Irons 2017). The apprentices echoed policy narratives extolling the virtues of specific skills acquisition (those valued by employers), while personalising these constructs by bringing in their current contexts and previous experiences. As such, policy implementation across all implementation agents had succeeded in creating a close alignment between study and work needs. This 'win' is not, however, guaranteed to be maintained as apprentices 
progress, and the situated realisation of work-based learning (positively expressed by apprentices in terms of introductory skills) becomes more challenging: progressing to increasingly advanced and specialised topics is likely to offer fewer opportunities for direct work skills integration. Furthermore, although prioritising professional standards was stated as a policy aim, it was not clear, from the apprentices' experience, how that would occur. Confused notions of professional standards reflects the IT industry, with its proliferation of new technology and vendor qualifications (Brockmann and Saraswat 2017).

While the framework approach to the employer-led curriculum delivers less financial risk to HEIs concerned about 'filling places', it also limits the extent of direct influence over the curriculum by single employers (Hordern 2014). The "ongoing negotiation and adaptation” (Sausman et al. 2016, 580) between policy implementation agents will determine the longer term winners and losers in that dichotomy, with maintenance of the currency of the curriculum a possible longer term casualty (Mulkeen et al. (2017).

\section{Implementation of the increased supply of skilled workers as a policy aim}

The aim to provide access to an increased number of skilled workers was expressed through new pathways into apprenticeships: vocational, experiential, and academic routes that would recognise diverse backgrounds. However, adverts for apprenticeships used standard university study awards to express desired qualifications and the apprentices, in the main, had achieved these standard school-level qualifications, with some having previously started (and dropped out of) a traditional computing-related degree course. Therefore, there was little evidence that the pool would increase significantly: instead many of the apprentices were using the opportunity to gain a recognised award, rather than as a vehicle to embark upon a new career. 
While HEIs act as policy implementation agents, and benefit from additional funded places, their role was downplayed in employer adverts and in policy documents. Indeed, years of attention to employability in the wider work-learning interface (for example, Scottish Funding Council 2014; Smith et al. 2017) was rather neglected in the promotion of this new route to becoming work-ready graduates in the policy narratives. Had universities previously neglected to link study with work? HEI adverts directed at potential apprentice employers paradoxically celebrated their prior credentials for partnership working on graduate skills. Quite where this leaves universities and their focus on work experience and work-integrated learning is not clear. Promoting the apprenticeship as an opportunity to gain valuable work experience while studying (or valuable study while working) is set in contrast with the traditional student who, by implication, has not been acquiring the necessary skills. While there is some evidence that apprenticeships have not reduced employers' appetite for offering work placements (NCUB 2018), there is clearly a danger that apprenticeship policy messaging could lead to employers favouring the apprentice degree over the traditional degree, employing graduate apprentices, rather than graduates (NCUB 2018). As such, the on-campus student may lose out - with employers critiquing traditional graduates as less-prepared for the workplace.

\section{Policy implementation - emergent challenges}

It is clear that the 'wins' will only be realised for those that complete their apprenticeship, and the role of the apprentice in negotiating and navigating the relationships, and making the policy work, should not be underestimated. This negotiation is not friction-free: the apprentices revealed a tension between work and study, in terms of balancing commitments. This supports observations from other degree apprenticeship implementation studies (Rowe 2018; UCAS 2017). UCAS (2017) 
suggest that the intense nature of studying a degree while working full-time may make these apprenticeships more suitable for those who have already begun their career rather than school-leavers, new to the workplace. As apprentices progress through the course, the nature of graduate-level employment may become clearer, for example, through promotions and salary increments. As apprentices’ careers progress, increases (or stasis) in professional recognition and salary may influence how they value the university degree further on in their course, with consequent impact on retention.

Certainly, the apprentices reiterated the novelty of their degree programmes, highlighting the benefits of being in work and able to apply university learning with immediacy. Finally, while apprentices were pleased to report skills transferred to their workplaces, employers may be more vulnerable to apprentice mobility due to the sectorbased approach to framework design.

\section{Conclusions and further work}

To conclude, we return to the three questions posed in the study, namely how the aims are framed in policy documents, how the providers and employers interpreted and expressed these aims and, finally, how the aims are reflected in the apprentices' experiences.

The apprenticeship policy aims were found to be framed primarily as meeting the needs of employers to access skilled employees. Degree apprenticeships were presented as an opportunity for employer and apprentice to benefit from multistakeholder collaboration in higher education and skills development. Indeed, in developing these models, the emphasis was placed on wins for all stakeholders. However, this study found a dominant rhetoric around employer-led approaches and responding to skills needs of industry and, as such, the role of the university was 
somewhat taken for granted. In practice, the degree framework approach served to diminish the extent to which employers could dictate content, while reducing policy implementation complexity for HEIs. In terms of apprentices’ experiences, most of the apprentices were already in work when they started the apprenticeship, implying the policy may have less influence than hoped as a gateway to employment and as a means to build a larger pool of skilled workers. However, the survey data indicates this is changing, with only 50\% of 2018 respondents already working for their apprenticeship employers, compared to 82\% of 2017 respondents.

In terms of future work, the longer term impact of policy implementation on HEIs, employers, and apprentices should continue to be examined to ensure the sustainability of the policy and maintain the vital interactions and relationships between all policy implementation agents. Studies should move from exploration of initial policy implementation to the interactions that make policy translation and enactment effective (Ball et al. 2012). Realising the win-win scenario is reliant on the continued possibility of the policy agenda and stakeholder expectations being negotiated in practice, acknowledging and resolving the emergent practical challenges and inevitable tensions. This is a significant challenge, especially as the scheme is scaled up. While the apprentices’ positive responses fit the win-win narrative, the diversity of their everyday life experiences indicates challenges for further development and expansion of the model. Enthusiasm is also tempered by restricted access to both subject frameworks and apprenticeship places.

Acknowledgements: Graduate apprenticeships are funded by Skills Development Scotland and the European Social Fund. 
1. The survey was completed by $22 / 28$ of the first cohort of computing apprentices and $47 / 50$ of the second; $15 / 28$ of the first cohort were interviewed. Any demographics apply to the research groups, rather than the full cohorts.

\section{References}

Ball, Stephen J. 2012. Politics and policy making in education: Explorations in sociology. Abingdon: Routledge.

Balloo, Kieran, Regina Pauli, and Marcia Worrell. 2017. "Undergraduates’ personal circumstances, expectations and reasons for attending university." Studies in Higher Education 42 (8): 1373-1384.

Bathmaker, Ann-Marie. 2013. “Defining 'knowledge’ in vocational education qualifications in England: an analysis of key stakeholders and their constructions of knowledge, purposes and content.” Journal of Vocational Education \& Training 65 (1): 87-107, DOI: 10.1080/13636820.2012.755210

BIS. 2016. Success as a knowledge economy: teaching excellence, social mobility and student choice (White paper). Department for Business Innovation and Skills. https://www.gov.uk/government/publications/higher-education-success-as-aknowledge-economy-white-paper

Boud, David, and Nicky Solomon. 2001. Work-based learning: a new higher education? Maidenhead: McGraw-Hill Education (UK).

Bowen, Glenn A. 2009. "Document analysis as a qualitative research method." Qualitative research journal 9 (2): 27-40. https://doi.org/10.3316/QRJ0902027

Braun, Virginia, and Victoria Clarke. 2006. "Using thematic analysis in psychology." Qualitative Research in Psychology 3 (2): 77-101.

Bravenboer, Darryll. 2016. "Why co-design and delivery is “a no brainer” for higher and degree apprenticeship policy." Higher Education, Skills and Work-based Learning 6 (4): 384-400.

Brockmann, Michaela, and Arti Saraawat. 2017. What do IT technicians do? Report for the Gatsby Foundation. http://www.gatsby.org.uk/uploads/education/reports/pdf/what-do-it-techniciansdo-report.pdf

Donnelly, Rory., Damian Grimshaw,, and Marcela Miozzo. 2011. "Does the UK have a 'comparative institutional advantage' that is supportive of the IT services sector?” New Technology, Work and Employment, 26(2): 98-112. 
Dziallas, Sebastian, and Sally Fincher. 2016. "Aspects of graduateness in computing students' narratives." In Proceedings of the 2016 ACM Conference on International Computing Education Research, 181-190. New York: ACM.

Elmore, Richard F. 1979. "Backward mapping: Implementation research and policy decisions." Political science quarterly 94 (4): 601-616.

Feldmann, Louisa, and Nicole Sprafke. 2015. "How to Design Empowering Workbased Learning Settings to Foster Students’ Competence Development." International Journal for Cross-Disciplinary Subjects in Education 6 (1): 20812089.

Gessler, Michael, and Falk Howe. 2015. "From the reality of work to grounded workbased learning in German vocational education and training: Background, concept and tools." International Journal for Research in Vocational Education and Training (IJRVET) 2 (3): $214-238$.

Green, Francis, Alan Felstead, Duncan Gallie, Hande Inanc, and Nick Jewson. 2016. "The declining volume of workers' training in Britain." British Journal of Industrial Relations 54 (2): 422 - 448.

Heriot-Watt University. 2018. "Bringing together the worlds of work and study" https://www.hw.ac.uk/business/our-stories.htm

Hill, Michael, and Peter Hupe. 2014. Implementing public policy: An introduction to the study of operational governance (3e). Sage, London.

Hjern, Benny. 1982. "Implementation research—the link gone missing." Journal of public policy 2 (3): 301-308.

Hodgson, Ann, Ken Spours, and David Smith. 2017. "Future apprenticeships in England: the role of mediation in the new model.” Journal of Education and Work 30 (6): 653 - 668. DOI: 10.1080/13639080.2017.1349299

Hordern Jim. 2014. "Workforce development, higher education and productive systems.” Journal of Education and Work 27 (4): 409-431.

Hupe, Peter. 2014. What happens on the ground: Persistent issues in implementation research. Public Policy and Administration, 29(2), 164-182.

Hupe, Peter and Michael Hill. 2016. ““And the rest is implementation’ Comparing approaches to what happens in policy processes beyond Great Expectations.” Public Policy and Administration 31 (2):103 - 121. 
Hupe, Peter., Michael Hill, and Monika Nangia. 2014. "Studying Implementation beyond Deficit Analysis: Reconsidering the Top-Down View”. Public Policy and Adminstration, 29(2):145-63.

Institute for Apprenticeships. 2017. 'How to' guide for trailblazers. London: Institute for Apprenticeships.

https://www.instituteforapprenticeships.org/media/1033/how_to_guide_for_trai lblazers_-_v2.pdf

Irons, Alastair. 2017. "Reflection on higher degree apprenticeship development.” Higher Education, Skills and Work-Based Learning 7(1): 112 - 122. DOI: 10.1108/HESWBL-05-2016-0033

Lambert, Steve. 2016. “Are current accountability frameworks appropriate for degree apprenticeships?” Higher Education, Skills and Work-Based Learning 6(4): 345-356. DOI: 10.1108/HESWBL-05-2016-0027

Lemanski, Tom, Ruth Mewis, and Tina Overton. 2011. An introduction to work-based learning. York: Higher Education Academy.

Maxwell, Joseph, and Kavita Mittapalli. 2011. A Realist Approach for Qualitative Research. Thousand Oaks: Sage.

Money, Julie, Sarah Nixon, Fran Tracy, Claire Hennessy, Emma Ball, and Track Dinning. 2017. "Undergraduate student expectations of university in the United Kingdom: What really matters to them?" Cogent Education 4 (1): 1- 11.

Mulkeen, James, Hussein A. Abdou, Jacqueline Leigh, and Paul Ward. 2017. "Degree and Higher Level Apprenticeships: an empirical investigation of stakeholder perceptions of challenges and opportunities." Studies in Higher Education 34 (2): 223 -236. DOI: 10.1080/03075079.2017.1365357.

NCUB. 2018. Degree Apprenticeships: impacts, challenges, future opportunities. National Centre for Universities and Business http://www.ncub.co.uk/images/reports/NCUB-Degree-Apprenticeships-ReportMar-18-WEB.pdf

Policy Connect. 2019. “Degree Apprenticeships Up to Standard?” Higher Education Commission https://www.policyconnect.org.uk/research/degree-apprenticeships$\underline{\text { standard }}$

Powell, Andy. 2019. “Apprenticeships and skills policy in England”. House of Commons Library 
https://researchbriefings.parliament.uk/ResearchBriefing/Summary/SN03052\#fu llreport

Powell, Philip, and Anita Walsh. 2018. "Whose curriculum is it anyway? Stakeholder salience in the context of Degree Apprenticeships.” Higher Education Quarterly 72 (2): 90-106. DOI: 10.1111/hequ.12149

Pülzl, Helga, and Oliver Treib. 2017. "Implementing public policy." In Handbook of public policy analysis: Theory, Politics, and Methods, edited by Frank Fischer, Gerald J. Miller, pp. 115-134. Abingdon: Routledge.

Radermacher, Alex, and Gursimran Walia. 2013. "Gaps between industry expectations and the abilities of graduates." In Proceeding of the 44th ACM technical symposium on Computer science education, 525 -530. New York: ACM.

Richard, Doug. 2012. The Richard Review of Apprenticeships. London: BIS. https://assets.publishing.service.gov.uk/government/uploads/system/uploads/atta chment_data/file/34708/richard-review-full.pdf

Robert Gordon University. 2018. “Why RGU?” http://www.rgu.ac.uk/businessservices/graduate-apprenticeships/why-rgu

Sabatier, Paul A. 1991. "Toward better theories of the policy process." PS: Political Science \& Politics 24(2): 147-156.

Sausman, Charlotte, Eivor Oborn, and Michael Barrett. 2016. "Policy translation through localisation: implementing national policy in the UK”. Policy \& Politics, 44(4):.563-589.

Schultz, Theodore W. 1961. "Investment in human capital." The American economic review 51 (1): $1-17$.

Scottish Funding Council (SFC) 2014. External summative evaluation of an investment in Learning to Work 2. Edinburgh: SFC.

http://webarchive.nrscotland.gov.uk/20171104031538/http://sfc.ac.uk/web/files/ reportsandpublications/learning_to_work_2_final_report.pdf

Scottish Government. 2014. Developing the Young Workforce: Scotland's Youth

Employment Strategy Edinburgh: Scottish Government http://www.gov.scot/Resource/0046/00466386.pdf

SDS. 2016a. Graduate Level Apprenticeships: Pathfinder Delivery 2016/17-2019/20.

Competitive Funding Offer Ref No. G16-026. Issued 22/11/2016. Skills

Development Scotland. 
SDS. 2016b. Graduate Level Apprenticeships at SCQF Level 10: Technical

Specifications. June 2016. Skills Development Scotland.

SDS. 2016c. Principles of Work Based Learning in Graduate Level Apprenticeships.

June 2016. Skills Development Scotland.

SDS, 2018. Graduate Apprenticeships. Skills Development Scotland.

https://www.skillsdevelopmentscotland.co.uk/what-we-

do/apprenticeships/graduate-apprenticeships/

Shadbolt, Nigel. 2016. "Shadbolt review of computer sciences degree accreditation and graduate employability." London: BIS.

https://www.gov.uk/government/publications/computer-science-degree-

accreditation-and-graduate-employability-shadbolt-review

Silverman, David, (ed.) 2016. Qualitative Research. London: Sage.

Smith, Sally, Colin Smith, Ella Taylor-Smith, and Julia Fotheringham. 2017. "Towards graduate employment: exploring student identity through a university-wide employability project." Journal of Further and Higher Education. DOI: 10.1080/0309877X.2017.1390077

Smithers, Alan. 2016. “The philosopher’s stone? The case for national apprenticeship qualifications”. In Where next for apprenticeships? Edited by Tess Lanning. 18-24. London: CIPD.

Taylor-Smith, Ella, Sally Smith, Khristin Fabian, Tessa Berg, Debbie Meharg, and Alison Varey. 2019. “Bridging the Digital Skills Gap: Are computing degree apprenticeships the answer?” In Proceedings of the 24th Annual Conference on Innovation and Technology in Computer Science Education (ITiCSE’19).. New York: ACM. https://doi.org/10.1145/3304221.3319744

Tech Partnership Degrees 2019. “Tech Industry Gold Accreditation” https://www.tpdegrees.com/about/tech-industry-gold-accreditation/ Thompson, Colin. 2008. "IT Professional role today and tomorrow." In E-Government Ict Professionalism and Competences Service Science, edited by A. Mazzeo, R. Bellini and G. Motta. 69-80. Boston, MA: Springer.

UCAS. 2017. Progression Pathways 2017: Pathways through higher education.

Cheltenham: Universities and Colleges Admissions Service (UCAS) https://www.ucas.com/files/progression-pathways-2017-report 
University of the West of Scotland (UWS). 2018. "What are Graduate

Apprenticeships?” https://www.uws.ac.uk/study/undergraduate/graduateapprenticeships/

Wakeham, William. 2016. Wakeham Review of STEM degree provision and graduate employability. London: BIS.

https://assets.publishing.service.gov.uk/government/uploads/system/uploads/atta chment_data/file/518582/ind-16-6-wakeham-review-stem-graduateemployability.pdf

Wilson, Tim. 2016. A review of business-university collaboration. London: BIS. https://assets.publishing.service.gov.uk/government/uploads/system/uploads/atta chment_data/file/32383/12-610-wilson-review-business-universitycollaboration.pdf 